\title{
THE BARRIERS TO SOCIAL INCLUSION \\ OF PEOPLE WITH DISABILITIES IN THE REPUBLIC OF MOLDOVA
}

\section{Parascovia MUNTEANU ${ }^{1}$, PhD in Sociology, State University of Moldova}

The social inclusion of people with disabilities is a current area of research. This group of people continues to be marginalized and excluded from the society's life. This situation is determined by the high level of discrimination and stigmatization, unequal opportunities, physical and attitudinal barriers that predominate in society. More than one billion people with disabilities worldwide, accounting $15 \%$ of the world's population, face social inequality and the authorities' limited capacities to respond to the needs of the persons with disabilities. In the European Union, about 80 million people live with disabilities and in the Republic of Moldova about 182.0 thousand people, which represent about 5\% of the country's population. This study aims to analyse barriers to social inclusion of people with disabilities from the Republic of Moldova from the perspective of social roles valorisation. The sociological research methods used in this study are statistical data analysis, documentary analysis; sociological survey based on the questionnaire; the focus group; in-depth interview and sociological observation. The main barriers to social inclusion faced by people with disabilities in the Republic of Moldova are: low living standards compared to the general population, non-observance of the general accessibility principle, limited access to social services, education, health and very low participation of people with disabilities on the labour market. Analysis of social inclusion issues identified through research on the views of people with disabilities, service providers and experts will help strengthen the mechanisms for evaluating, monitoring and improving social inclusion policies.

Keywords: social inclusion, exclusion, disability, social policies, inclusion issues, accessibility, participation, non-discrimination, institutional mechanisms.

Incluziunea socială a persoanelor cu dizabilități constituie un domeniu actual de cercetare. Acest grup de populație continuă să fie marginalizat și exclus de la viața societății. Situația dată este determinată de nivelul înalt al discriminării și stigmatizării, oportunităților inegale, barierelor fizice și atitudinale care predomină în societate. La nivel mondial, peste un miliard de persoane cu dizabilități, ceea ce constituie cca $15 \%$ din populația lumii se confruntă cu probleme de inechitate socială și incapacitatea autorităților de a răspunde nevoilor. În Uniunea Europeană, circa 80 milioane de persoane trăiesc cu dizabilități, iar în Republica Moldova sunt circa 182.0 mii persoane, ceea ce constituie aproximativ 5\% din populația țării. În acest articol sunt prezentate rezultatele cercetării barierelor de incluziune socială a persoanelor cu dizabilități din Republica Moldova din perspectiva valorizării rolurilor sociale. Metodele de cercetare sociologică utilizate la realizarea acestui studiu sunt: analiza datelor statistice, analiza documentară; ancheta sociologică în bază de chestionar; metoda focus-grupului; metoda interviului aprofundat și observația sociologică. Principalele probleme și bariere ale incluziunii sociale cu care se confruntă persoanele cu dizabilități din Republica Moldova sunt: nivelul de trai scăzut comparativ cu populația generală, nerespectarea principiului general al accesibilității, accesul limitat la servicii sociale, educaționale, de sănătate, și participarea foarte scăzută a persoanelor cu dizabilități pe piața muncii. Analiza problemelor incluziunii sociale identificate în urma cercetării opiniilor persoanelor cu dizabilități, ale prestatorilor de servicii și ale experților va contribui la consolidarea mecanismelor de evaluare și îmbunătăţire a politicilor de incluziune socială și la consolidarea mecanismelor instituționale de monitorizare a politicilor de incluziune socială.

Cuvinte-cheie: incluziune socială, excluziune, dizabilitate, bariere ale incluziunii, oportunități, accesibilitate, participare, nediscriminare, mecanisme instituţionale. 
Социальная инклюзия людей с ограниченными возможностями является актуальной областью исследований. Эта группа людей продолжает оставаться маргинализованной и исключенной из жизни общества. Эта ситуация определяется высоким уровнем дискриминации и стигматизации, неравными возможностями, физическими и поведенческими барьерами, которые преобладают в обществе. Более одного миллиарда людей с ограниченными возможностями во всем мире, что составляет около 15\% населения, сталкиваются с социальным неравенством и недостаточным действием властей по удовлетворению их потребностей. Около 80 миллионов человек с ограниченными возможностями живут в Европейском Союзе, а в Республике Молдова около 182,0 тысяч человек, что составляет около 5\% населения страны. Целью данного исследования является анализ барьеров в социальной интеграции людей с ограниченными возможностями в Республике Молдова через призму повышения их социальных ролей в обществе. Методы социологического исследования, используемые в этом исследовании: статистический анализ данных, документальный анализ, социологический опрос на основе анкетирования; фокус-группа; углубленное интервью и социологическое наблюдение. Основные проблемы и препятствия для социальной интеграции, с которыми сталкиваются люди с ограниченными возможностями в Республике Молдова являются: низкий уровень жизни по сравнению с населением в целом, несоблюдение принципа общей доступности, ограниченный доступ $к$ социальным услугам, образованию, здравоохранению и очень низкий уровень участия людей с ограниченными возможностями на рынке труда. Анализ проблем социальной интеграции, выявленных в результате исследований у лиц с ограниченными возможностями, поставщикам услуг и экспертам, поможет укрепить механизмы оценки, мониторинг и совершенствования политики социальной интеграции.

Ключевые слова: социальная интеграция, исключение, ограниченные возможности, проблемы интеграции, доступность, участие, недискриминация, возможности и ресурсы, институциональные механизмы.

DOI: https://doi.org/10.36004/nier.es.2019.1-09

JEL Classification: H75, I14, I38

UDC: 364.262(478)

Relevance of the research. The social inclusion of people with disabilities is a relevant area of research. This group of people is still marginalized and excluded from the life of the society. This situation is determined by a high level of discrimination and stigmatization, unequal opportunities, physical and attitudinal barriers that predominate in the society. At the same time, people with disabilities face the highest rate of poverty, they have shortages and the lowest incomes in comparison with the rest of population. The poverty has a direct impact upon their health condition, participation and accomplishment of their social roles, leading to their exclusion and auto-exclusion. Out of the overall number of people with disabilities in the Republic of Moldova, approximately 2000 people still live in residential institutions.

At the global level, over a billion of people with disabilities, representing $15 \%$ of the world's population, face problems of social inequity and the authorities' incapacity to satisfy their needs. Approximately 80 million people in the European Union have disabilities [7, p. 3]. At the same time, there are almost 182.0 thousand people with disabilities in the Republic of Moldova; it constitutes nearly 5\% of the population of the country [17]. In the Republic of Moldova, the lower rate of people with disabilities compared with the rate at the European and global level can be explained by the differences in the groups included in the statistical data. Thus, the data regarding people with disabilities in the Republic of Moldova does not include pensioners of age limit with disabilities, people with disabilities who benefit from the state complete support, children between 0 and 3 years old and people with disabilities who have no certificate of determining disability and working capacity. If the statistical data also included these groups of people, the rate of people with disabilities in the Republic of Moldova would be much higher that it actually is.

The social inclusion of people with disabilities in the Republic of Moldova became a priority for the Government, being stipulated in the Action Plan for implementing the Association Agreement between the Republic of Moldova and the European Union. In the same direction the State has assumed this responsibility when ratifying the UN Convention on the Rights of Persons with 
Disabilities in 2010 [5]. However, neither the people with disabilities, nor the service providers in the domain do not observe some significant changes of the situation. The State, having these responsibilities and being under the society pressure, started to develop certain policies related to the social inclusion of people with disabilities. The UN Committee has observed that the medical approach of disability still predominates in the Republic of Moldova; the policies related to social inclusion are approached sectorial and considered to be the responsibility of the Ministry of Health, Labor and Social Protection without any clear mechanisms of coordination between all governmental institutions [19].

The relevance of the research domain results, also, from the fact that the stigmatizing and discriminatory attitudes towards the people with disabilities, along with inaccessibility and lack of services at the community level, predominate in our society. Even though there is a developed and approved policy framework in certain domains. These policies are not so easy to implement because the reforms do not have the necessary financing, as well as because of low level of informing and awareness about the problem by the central and the local public authorities, the private institutions, the civil society and the general population.

The goal of this paper is to analyse the barriers of social inclusion of people with disabilities and the degree of implementing the social policies elaborated in the last years and issuing practical recommendations in order to improve the institutional mechanism of developing, implementing and monitoring the current framework of policies that shall comprise all aspects of social inclusion.

The degree of scientific approach of the domain of research. The theoretical and methodological background of the research is represented by the fundamental sociological theories. According to the structural-functionalist theory (A. Compte, E. Durkheim, M. Weber), a society represents a functioning social system that offers to its members opportunities of social inclusion by eliminating the barriers. The theory of stigmatization (E. Goffman) stipulates that an unusual attribute or stigma of a person may underline him and cause other society members' separation from him. The theory of social role valorisation (W. Wolfensberger) that forms the theoretical and scientific basis of substantiating the concept of disability and determining the model of disability approach through the prism of attributing valuable social roles to people with disabilities is very important for investigating the barriers of inclusion [20]. At the same time, the social inclusion of people with disabilities was analysed from the perspective of specific theories applied in the practice of social assistance (theory of care, theory of attachment, theory of participation) described by M. Bulgaru and M. Dilion in the work Concepte fundamentale ale asistenței sociale [2].

At the European Union level, the researches carried out by A. Lawson [10] and L. Gronvik [8] address the social inclusion barriers faced by the people with disabilities in different areas of interest negotiated with the Council of Europe and with the authorities of the member states. The main domains of research are the following: accessibility, access of people with disabilities to the services of support for their independent life in the community, inclusive education, employment, monitoring the social inclusion policies at the European Union level according to the EUROSTAT indicators etc.

In Romania, the issues of social inclusion represent a domain of research for D. Arpinte [1], L. Manea [15] and M. Preda [16], who analyse the indicators of monitoring the groups with an increased risk of social exclusion. According to this analysis, the recommendations for social policies focused on evidence and needs are elaborated.

In the Republic of Moldova, L. Malcoci [13,14], M. Vremeș, D. Vaculovschi, V. Craevschi-Toartă [18] studied initially the process of inclusion as an answer to the social exclusion situations and afterwards analysed the process of inclusion of disadvantaged groups, as well as the problems faced by them in the process of social inclusion.

It is worth mentioning that most of the researches from the domain focus on certain aspects of inclusion. There are no comprehensive sociological researches that address all aspects of social inclusion of people with disabilities from the perspective of social role valorisation taking into account the opinions of people with disabilities, service providers and experts from the domain.

Methodology of research. In order to study the barriers of social inclusion of people with disabilities from the Republic of Moldova we used a methodology on a representative sample at the national level that allows carrying out a multidimensional research. It were used the sociological 
survey based upon the questioning of 1108 people with disabilities who live in families; 59 interviews with people with intellectual disabilities who live in residential institutions; 20 in depth interviews with experts in the field and 5 focus group discussion with participation of 43 representatives of social services providers. The methods of sociological research used while carrying out this study are the following: statistical data analysis; documentary analysis; sociological survey based upon a questionnaire; focus group method; in-depth interview and the sociological observation. The research period is 2017-2018 years.

Results of research. This compartment of the study includes the analysis of the process of social inclusion of people with disabilities by identifying the barriers that influence their living standard and their full participation in the social life based upon the general principle of accessibility, the access to social, educational and healthcare services and their presence on the labour market.

Approximately $31 \%$ of the interviewed people with disabilities, in comparison with $47 \%$ of the general population, mentioned that the income they disposed of was enough only to cover their absolute necessities. Only $4 \%$ of the interviewed people with disabilities, in comparison with $17 \%$ of the general population, mentioned that the income they disposed of was enough for a decent living standard, without expensive things. Only $1 \%$ of the interviewed people with disabilities, in comparison with $5 \%$ of the general population, mentioned that the income they disposed of was enough for a decent living standard, as well as for expensive things [9].

The rate of people who have mentioned that their income does not cover even their absolute necessities is higher among the unemployed people with disabilities (72\%), people with lower level of education (71\%) and people with mental disabilities (75\%) [17, p. 21].

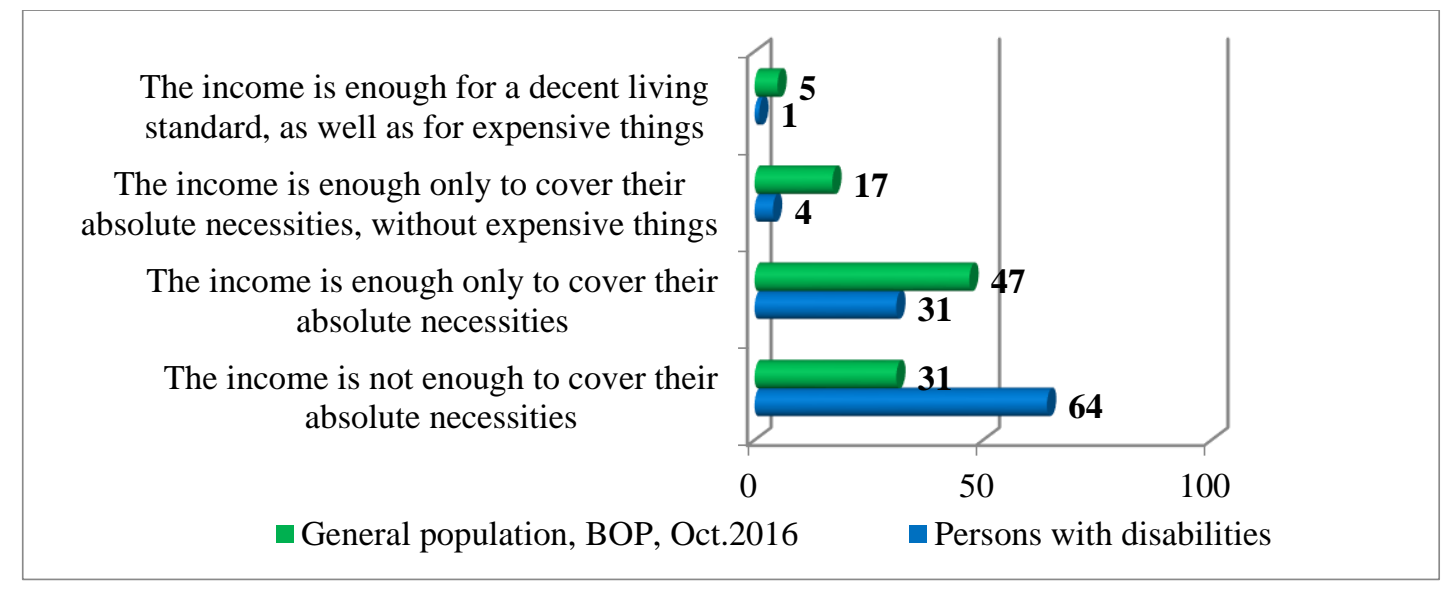

Figure 1. Perceptions of the people with disabilities and the general population about the income they dispose of, $\%$ Source: Malcoci L., Munteanu P. Studiu sociologic: Incluziunea socială a persoanelor cu dizabilităţi [14, p. 19].

The reduced incomes of people with disabilities limit their access to various goods and services, firstly, to the strictly necessary ones: clothes, shoes, food, drugs, water, heating and sewerage services. The results of field research show that the people with disabilities are able to cover fully or to a large extent only the monthly expenditures for electricity, water, sewerage and telecommunications (phone, TV, Internet). Fewer people afford paying for heating, transport, drugs, vegetables and fruits. Even a smaller number of people can purchase with their income clothes, shoes, meat or dairy products. Almost nobody can afford a holiday with the family once in a year, new furniture and new home appliances, or pay for the recovery and rehabilitation services. At the same time, the low incomes of people with disabilities are enough neither for creating normal living conditions, nor for ensuring the minimum consumption basket.

According to the results of the research, we can conclude that the living standard of the people with disabilities, apart from the income, living conditions and the access to utilities, depends very much upon the support received by the person from the loved ones and upon the relationships with 
them built through the years [14]. "The life of a person with disabilities depends very much upon the support group he has at the levels of family, community and society. The larger the group of support, the more intense the life is and the more various the social roles acquired by the person are. An active life means inclusion" [in-depth interview with a person with disabilities].

The most of service providers and experts from the domain have mentioned that there is a significant connection between the living standard and the social inclusion of people with disabilities. The small and non-diversified incomes are the main cause of the low living standard. The public authorities do not pay an increased attention to studying and evaluating the living standard of people with disabilities. This is the reason why the policies of social inclusion do not provide specific measures for improving the situation. The National Bureau of Statistics so far does not calculate the monthly consumption basket for people with disabilities. However, it is a very important criterion in evaluation and investigation of the living standard. The experts from the domain consider that one of the barriers that prevent determining the minimum consumption basket is the fragmentation of allowances for people with disabilities, depending on their contribution to the budget of social insurances, the disability type and its degree of severity. This fragmentation of social allowances for people with disabilities creates "confusions in the process of their management among officials as well as among people with disabilities, without any real impact on their well-being" [in-depth interview with an expert from the Ministry of Finance]. Besides that, the amount of social allowances is miserable in comparison with the minimum consumption basket and the state does not take any measures for their increase because of the lack of financial resources.

The research results highlight the fact that the living standard of the people with disabilities contributes directly to the process of social inclusion. Thus, the process of social inclusion of people with disabilities is longer and more difficult because the households where at least one family member has a disability, still have a disadvantage in comparison with the households without people with disabilities. The people with disabilities represent the group with the lowest incomes in comparison with the general population. Their income is equal to approximately $40 \%$ of the value of the minimum consumption basket; the rate of people with disabilities who are not able to cover their absolute necessities is twice as high as the same rate among the general population.

This study also investigates the inclusion barriers faced by people with disabilities depending upon a set of indicators, namely: the general principle of accessibility, the access to social, educational and healthcare services and the presence of people with disabilities on the labour market.

From the perspective of accessibility, the social inclusion of people with disabilities highlights the problems, which prevent the people with disabilities to live independently and to fully participate in all life aspects. The Convention, as well as the Law on social inclusion of people with disabilities, defines accessibility as a set of measures which comprises identifying and eliminating the obstacles and the barriers to the full access, in equal terms with the others, to physical environment, transport, information and means of communication, including the IT and communication technologies and systems, as well as to other facilities or services opened and offered to public in urban and rural areas [12].

The analysis of legal and normative documents that regulate ensuring accessibility conditions for people with disabilities in the Republic of Moldova shows that a set of normative documents with the content based upon the Law on social inclusion of people with disabilities has not been elaborated yet. The set lacks the following documents: the national policy of reasonable accommodation; the norms of reasonable accommodation; the standards of transport accessibility and the minimum requirements for universal design. Every third person with disabilities questioned during the research considers that the absence of accessibility is one of the main reasons why the people with disabilities feel completely or partially isolated from their community [14, p. 40-41].

The results of the performed analysis show that so far there is no policy document describing the main measures and requirements in order to ensure accessibility in conformity with the principles of reasonable accommodation and universal design. In comparison to the social inclusion practices in the EU member states, depending upon the principle of accessibility, the Republic of Moldova is very poor at the level of legal and normative regulations, as well as at the practical level of ensuring accessibility. For these reasons, the absence of accessibility represents one of the main problems of the social inclusion process. 
The investigation of social inclusion with respect to the access of people with disabilities to social services was approached being based on the Law No. 123 from June, 23, 2010 on social services. According to this law, people with disabilities from the Republic of Moldova may have access to different types of social services: primary specialized and highly specialized. Mostly, the primary social services are provided at the community level, but the specialized and highly specialized services are provided at the level of district, region or republic [11].

During the research, we analysed the system of social services provided from the public resources and found that approximately 24 types of social services for all groups of population are financed from the state budget and from the budgets of the administrative territorial units. The people with disabilities are eligible for 14 types of social services. The regulatory framework of creating and functioning of the last 7 types of social services was developed with the support from the civil society organizations after the Convention had been ratified. Despite the fact that innovative social services for people with disabilities were developed in the last years, the participants in the research (questioned people with disabilities and experts) mentioned that these services were unevenly developed, were not sufficient and did not meet all special needs of people with disabilities. Only $23 \%$ of the questioned people with disabilities mentioned that in comparison to 2010 there are more social services for people with disabilities at the level of community and district, $63 \%$ mentioned that they did not see any difference and $14 \%$ of the respondents could not give an answer. The analysis of the system of the services developed by the local public authorities highlighted the fact that some administrative territorial units do not have any type of specialized social services. The people with disabilities from these communities have access only to services provided by the community social worker. Every third person with a disability questioned during the research considers that the absence of social services is one of the main reasons why the people with disabilities feel completely or partially isolated from the community [14, p. 40-41].

In the opinion of experts, there is no national mechanism of coordinating the development of social services at the level of administrative territorial units based upon the individual needs and evidences. Most of specialized social services are developed in collaboration with non-governmental organizations and financed by donors in the districts where the public authorities are more open to pilot new services. In these conditions, some essential risks appear: (a) in the districts where the local public authorities are more reluctant to social services, the people with disabilities have no possibility to access services in conformity to their needs; (b) in the districts where more services are developed as soon as the district authorities and their priorities change, the sustainability of some social services can be exposed to a major risk.

The experts have also mentioned that in some cases the social services are developed without having initially a strategy of ensuring the financial sustainability. Many services do not have regulations on functioning and standards of quality and, as a result, cannot be accredited. According to experts' opinion, "if the social services are managed by the local public authorities and depend upon the amount of local financing, people with disabilities will still have a limited and unfair access to social services. The service of personal assistance is an eloquent example in this context. Even though this service is very necessary for the people with severe disabilities, who need a continuous care, the capacity of local authorities to allocate resources in order to increase the number of personal assistants is reduced because of the budgetary austerity" [in-depth interview with an expert from the Ministry of Health, Labour and Social Protection].

The investigation of social inclusion of people with disabilities from the perspective of education was focused on the identification of the barriers to access to educational services by analysing the services of support for inclusive education; by determining whether there are services of support for the period of transition of people with disabilities from one level of education to another, and by analysing the policies and practices of inclusive education. Regarding the access to education of children with disabilities, the regulatory framework of the Republic of Moldova [4] includes provisions related to the equality of opportunities to access to education for all children. The Republic of Moldova is a signatory to the Convention of the Rights of the Child and the Convention on the Rights of Persons with Disabilities. Both of these documents support that political engagement should ensure the opportunities and the access to a high-quality education for all children, including children with disabilities.

In this context, the authorities had to face the following barriers: lack of support services for children with severe disabilities, as well as for children with sensory disabilities; lack of social services for children with disabilities; lack of legal framework in order to ensure the financing of the supporting 
services for inclusive education; the lack of statistical data that may serve as a basis for planning the programs. This fact makes it necessary to map the support services [3, p. 23-24].

The inclusion of the people with disabilities in educational institutions is conditioned by the general policies of education promoted at the national and at the local level. It is worth mentioning that the incomes and the residence of people with disabilities influences the opportunities to continue their studies after graduating from a secondary school or a lyceum. According to the results of the research, the people with disabilities from rural area plead mostly for professional studies, while those from urban area plead for continuing their studies at colleges and universities. It can be explained by the better access of the people with disabilities from urban areas to studies and employment in comparison to those from rural areas. The analysis of the results, open interviews and discussions from the focus groups highlights the fact that the problem of respecting the right to education of the people with disabilities in institutions of professional studies and higher education is still relevant despite the public authorities' policies aimed to ensure the inclusive education.

According to experts, Moldova registered positive changes in the domain of inclusive education in comparison with 2010. However, there is still a lot to do; the process of inclusion in general education is still quite difficult. At the same time, the experts mentioned that there were almost no changes related to inclusive education in professional and secondary specialized studies. They say that the secondary professional and specialized education is not attractive enough, being too expensive for the state.

The research of social inclusion of people with disabilities with respect to their access to healthcare services highlights the fact that the services of primary, specialized and hospital medical care are not fully provided to people with disabilities. One of the main challenges is related to the reduced degree of accessibility of healthcare services determined by the lack of adapted infrastructure of medical institutions, especially in rural areas. Even though the people with disabilities benefit from a free medical insurance from the system of medical insurances, they receive partially or do not receive at all some necessary drugs, because these expenditures are not covered from the state funds of medical insurances. Thus, the results of the research of social inclusion of people with disabilities show that $69 \%$ of the questioned people with disabilities have access to healthcare services in equal measure with other citizens, $10 \%$ consider that they have more benefits related to the access to healthcare services in comparison to the others and $18 \%$ of the respondents think that they have fewer possibilities to access medical services.

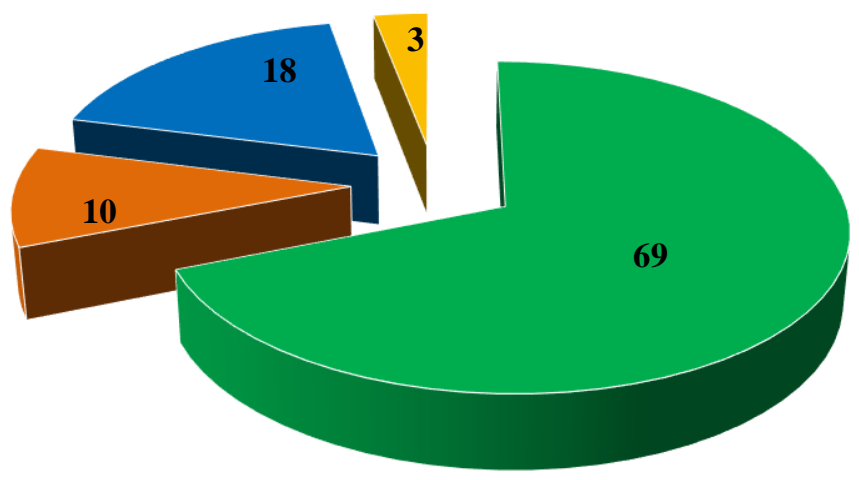

- Have access to healthcare services in equal measure with other citizens

- Have more benefits related to the access to healthcare services in comparison to the others

- Have fewer possibilities to access medical services.

N/A

Figure 2. Respondents' opinions regarding their access to social services, \% Source: Malcoci L., Munteanu P. Studiu sociologic: Incluziunea socială a persoanelor cu dizabilități [14, p. 36].

The results of the qualitative research carried out according to the experts' opinions about the social inclusion with respect to the access of people with disabilities to healthcare services highlighted many barriers faced by people with disabilities during the access to healthcare services. One of these barriers refers to the impossibility of the people with severe mobility disabilities to benefit at home 
from services of specialized medical assistance. On the one hand, these people are able to go to medical institutions; on the other hand, the medical institutions do not have conditions of physical accessibility for wheelchairs and for appointment to the specialists (neurologist, cardiologist etc.) who may go home to people with severe disabilities.

The reduced access of people with disabilities to free services of prosthetics, rehabilitation and recovery justified by the experts with insufficiency of resources allocated by the public local authorities leads to inclusion problems caused by the reduced mobility of people with disabilities. Thus, the research results demonstrate that the access of people with disabilities to healthcare services represents one of the pillars of the social inclusion process at all levels. The problems that prevent the process of social inclusion in the domain of healthcare are the following: absence of physical accessibility and of modern medical equipment accessible for everyone, limited access to free healthcare services and compensated drugs, inefficient collaboration between medical institutions of all levels, as well as between medical institutions and those of social protection and assistance.

The research of social inclusion with respect to participation of people with disabilities in the labour market aims to identify and analyse the problems faced by people with disabilities regarding their employment. The level of workforce employment decreases continuously. The working population leaves abroad because the jobs in Moldova are not well paid. Those who do not leave prefer either not to work, benefitting from remittances from abroad or from social allowances. When the lack of qualified workforce becomes an important constraint for employers, the employment policies should be oriented inclusively towards promoting employment services among people with disabilities.

The valorisation of experience of people with disabilities accumulated in a non-formal and an informal context represents an essential factor for ensuring the access of the person to work. It is worth mentioning that $78 \%$ of people with moderate or accentuated disabilities graduated from at least one educational institution. Every fourth person out of them graduated from a professional school; it is an advantage for the labour market because there are major problems related to lack of human resources or large fluctuation of employees. Besides that, around $67 \%$ of the respondents involved in the research have mentioned that they are not employed now but have been employed before. Most of them left their job because of disability, because they did not have the necessary support for adapting the workplace, or in order to be able to benefit from social allowances, although keeping the job does not affect in any way the person's right to disability allowances, others were fired by their employers because of their disabilities.

The results of the research highlight several problems that prevent ensuring the right to work of people with disabilities: reduced level of information; lower self-esteem and motivation of people with disabilities; the problem of professional training and qualification; reduced quality of secondary professional education, secondary specialized education or higher education that contributes directly to enlarging or narrowing the possibilities of employment.

General conclusions and recommendations. The main problems of social inclusion faced by the people with disabilities from the Republic of Moldova are the following: the decreased living standard in comparison to general population; the infringement of general principle of accessibility; the limited access to social, educational and healthcare services and a very low participation of people with disabilities in the labour market.

The living standard, as an important dimension of the process of social inclusion of people with disabilities, denotes the existence of social inequalities in comparison to the general population; it has a negative influence upon the process of social inclusion. This aspect of inclusion highlights the problems preventing people with disabilities from having a decent living standard. In order to overcome the barriers of social inclusion faced by people with disabilities, according to the results of the research, a set of recommendations is suggested to the authorities:

1. To improve the system of social welfare of people with disabilities by revision of the way of calculating and offering social allowances in line with individual needs for fulfilling the social roles; delimitation of money amounts that may be considered sources of income from the social allowances offered for care. Estimation by the National Bureau of Statistics of the minimum consumption basket for people with disabilities depending upon: the degree of severity of disability (severe, accentuated, and moderate) and the employment status (employed, unemployed). 
2. To increase the access of people with disabilities to education, including the vocational one, by development of support services in all educational institutions in order to increase the access to studies for people with disabilities. Development of continuous training programmes, including programmes of learning at home for adults with disabilities; improvement of services of professional re-qualification for the people who got their disability during the life.

3. To increase the access of people with disabilities to healthcare services by including some specialized medical services (consultations of neurologist, cardiologist, psychiatrist, orthopaedist etc.) at home for the people with severe mobility disabilities into the set of medical services covered by the National Company of Medical Insurances. Revising the list of compensated drugs; ensuring the accessibility of medical infrastructure and informational materials for people with all types of disability.

4. To increase the access of people with disabilities to social services by developing public policies in the domain of disability on the basis of evidence and evaluation of the social impact. Empowering the local and national public authorities in the context of ensuring the rights of people with disabilities to benefit from social services depending upon their needs. Re-evaluating the current system of social services and modifying it in conformity with the present needs of the people with disabilities. Revising the mechanism of financing the social services and the staff structure from the perspective of social role valorisation of people with disabilities.

5. Increasing the employment of people with disabilities by strengthening active measures of stimulation of the workforce employment. Elaborating, approving and applying a mechanism of creation, reservation and keeping the workplaces in line with the provisions of the Law on social inclusion of people with disabilities. Elaborating mechanisms of stimulation and subsidisation of the employers who have additional expenditures for reasonable accommodation of the workplaces reserved for people with disabilities. Promoting practices of supported employment piloted by the civil society organizations at the national level.

\section{REFERENCES}

1. ARPINTE, Daniel, BABOI, Adriana ș.a. Politici de incluziune socială. In Calitatea vieții. 2008, anul XIX, nr. 3-4, pp. 339-369. [Accesat 16.11.2018]. Disponibil: http://www.revistacalitateavietii.ro/2008/CV-3-4-2008/07.pdf

2. BULGARU, M., DILION, M. Concepte fundamentale ale asistenței sociale. Chișinău: USM, 2000.316 p. [Accesat 16.11.2018]. Disponibil: http://prometheus.usm.md/crras.usm.md/CRRAS/manualepdf/concepteas.pdf

3. CARA, Angela. Asigurarea unei educații de calitate pentru toți copiii. Sinteză de politici în domeniul educației. Chișinău: IPP, 2017. 28 p. [Accesat 16.02.2019]. Disponibil: http://ipp.md/wpcontent/uploads/2017/09/Sinteza-Cara-Angela.pdf

4. Codul Educaţiei al Republicii Moldova: nr. 152 din 17.07.2014. In: Monitorul Oficial al Republicii Moldova. 2014, nr. 319-324, art. 634. [Accesat 21.03.2019]. Disponibil: http://lex.justice.md/index.php?action=view\&view=doc\&lang=1\&id=355156

5. Convenţia ONU privind drepturile persoanelor cu dizabilităţi ratificată de Parlamentul Republicii Moldova prin Legea: nr. 166 din 09.07.2010. In: Monitorul Oficial al Republicii Moldova. 2010, nr. 126-128, art. 428. [Accesat 21.03.2019]. Disponibil: http://lex.justice.md/index.php?action=view\&view=doc\&lang=1\&id=335376

6. DURKHEIM, Emile. Regulile metodei sociologice. Iași: Polirom, 2002. 192 p. https://monoskop.org/images/8/8b/Durkheim_\%C3\%89mile_Regulile_metodei_sociologice_2002. pdf

7. European Disability Strategy 2010-2020 approved by European Commission: a renewed commitment to a Barrier-Free Europe. Brussels, 2010. 12 p. [Accesat 21.03.2019]. Disponibil: https://eur-lex.europa.eu/LexUriServ/LexUriServ.do?uri=COM:2010:0636:FIN:en:PDF

8. GRONVIK, Lars. Definitions of Disability in Social Sciences: methodological perspectives. Uppsala: Uppsala University Phd disertation, 2007. 52 p. [Accesat 21.03.2019]. Disponibil: https://uu.divaportal.org/smash/get/diva2:170048/FULLTEXT01.pdf 
9. Barometrul Opiniei Publice. Institutul de Politici Publice. Chișinău, 2016, octombrie. [Accesat 10.01.2019]. Disponibil: http://ipp.md/old/libview.php?l=ro\&idc=156\&id=804

10. LAWSON, Anna. Access to Accessibility of Citizenship and Political Participation of People with Disabilities in Europe: introduction to two related 2013 ANED reports: synthesis report. Leeds: University of Leeds, $2013.59 \mathrm{p}$.

11. Legea cu privire la serviciile sociale: nr. 123 din 18.06.2010. In: Monitorul Oficial al Republicii Moldova. 2010, nr. 155-158, art. 541. [Accesat 10.01.2019]. Disponibil: http://lex.justice.md/index.php?action=view\&view=doc\&lang=1\&id=335808

12. Legea privind incluziunea socială a persoanelor cu dizabilităţi: nr. 60 din 30.03. 2012. In: Monitorul Oficial al Republicii Moldova. 2012, nr. 155-159, art. 508. [Accesat 10.01.2019]. Disponibil: http://lex.justice.md/index.php?action=view\&view=doc\&lang=1\&id=344149

13. MALCOCI, Ludmila, ASTRAHAN, Arcadie. Convenția ONU privind drepturile persoanelor cu dizabilități: ghid pentru administrația publică locală. Chișinău: Keystone Moldova, 2013. 69 p. [Accesat 10.01.2019]. Disponibil: https://www.soros.md/files/publications/documents/Anexa\%201\%20Conventia\%200NU\%20\% 20ghid\%20pentru\%20APL.pdf

14. MALCOCI, Ludmila, MUNTEANU, Parascovia. Incluziunea socială a persoanelor cu dizabilități din Republica Moldova: studiu sociologic. Chișinău: Arva Color, 2017. 60 p. [Accesat 10.01.2019]. Disponibil: https://www.soros.md/files/publications/documents/Studiu\%20Incluziunea\%20Sociala\%20a\%2 0Persoanelor\%20cu\%20Dizabilitati\%202017.pdf

15. MANEA, Livius. Dizabilitatea ca factor de risc în accesarea serviciilor de educație. In: Calitatea vieții. 2006, anul XVII, nr. 1-2, pp. 41-50. [Accesat 10.01.2019]. Disponibil: https://www.revistacalitateavietii.ro/2006/CV-1-2-06/4.pdf

16. PREDA, M., POP, Luana Miruna. Dicţ̧ionar de politici sociale. Bucureşti: Ed. Expert, 2002. 874 p.

17. Situația persoanelor cu dizabilități din Republica Moldova pentru anii 2015-2016. Biroul Naţional de Statistică. 2015. [Accesat 15.04.2019]. Disponibil:

http://www.statistica.md/newsview.php?l=ro\&idc=168\&id=4976

18. Raportul naţional al dezvoltării umane al Republicii Moldova. Dincolo de tranziţie: De la Excluziune Socială spre o Dezvoltare Umană Incluzivă. Chișinău: Nova Imprim, 2010. 168 p. [Accesat 12.02.2019]. Disponibil: http://old.mts.gov.md/content/raportul-national-al-dezvoltarii-umanerepublica-moldova-dincolo-de-tranzitie-de-la

19. Observațiile finale referitoare la raportul inițial al Republicii Moldova. Comitetului ONU, Convenţia privind drepturile persoanelor cu dizabilităţi. 2017, 12 aprilie. [Accesat 18.04.2019]. Disponibil: http://cdpd.md/wp-content/uploads/2018/01/Recomand\%C4\%83rile-Ro-UN-CRPD.pdf

20. WOLFENSBERGER, Wolf. Social Role Valorization. New York: Syracuse University, 2004. 139 p. 